\title{
Synthesis and thermal behaviour of new benzo-1,2-thiazine long-chain aryl-piperazine derivatives
}

\author{
Edward Krzyżak • Berenika Szczęśniak-Sięga • \\ Wiesław Malinka
}

Received: 4 December 2012/Accepted: 5 April 2013/Published online: 30 April 2013

(C) The Author(s) 2013. This article is published with open access at Springerlink.com

\begin{abstract}
A series of potential biologically active 2-[3(4-phenyl-1-piperazinyl)propyl]-3-(4-substituted-benzoyl)4-hydroxy-2H-1,2-benzothiazine 1,1-dioxides was synthesized in a straightforward manner by condensation of respective 3-substituted-4-hydroxy-1,2-benzothiazine 1 , 1-dioxides with 1-(1-chloropropyl)-4-phenylpiperazine. The structures of all of the newly formed compounds were identified by elemental analysis, FTIR and ${ }^{1} \mathrm{H}$ NMR. The synthesized compounds were subjected to preliminary evaluation using differential scanning calorimetry (DSC) to determine the existence of multiple crystal forms. The DSC scans for all compounds show more than one endothermic effect, which might suggest dynamic proton transfer between two or three possible tautomeric forms: $O$-keto/O-enol, $O$-enol $/ O$-keto and $O$-keto/O-keto/ $/ \mathrm{CH}_{2}$ in crystals 2-[3(4-phenyl-1-piperazinyl)propyl]-3-(4-substituted-benzoyl)4-hydroxy-2H-1,2-benzothiazine 1,1-dioxides.
\end{abstract}

Keywords DSC - Benzothiazine - Thermal analysis · Tautomeric isomers $\cdot$ Synthesis

\section{Introduction}

Sundry benzothiazine derivatives are known to possess a wide spectrum of biological activities like anti-inflammatory [1], analgesic and antipyretic [2], antimicrobial [3], antiviral [4],

\section{E. Krzyżak (ه)}

Department of Inorganic Chemistry, Wrocław Medical University, ul. Borowska 211A, 50-556 Wrocław, Poland

e-mail: edward.krzyzak@umed.wroc.pl

B. Szczęśniak-Sięga · W. Malinka

Department of Chemistry of Drugs, Wrocław Medical

University, ul. Borowska 211, 50-556 Wrocław, Poland antitumor [5], antidiabetic [6] and Alzheimer's and Parkinson's disease treatment [7]. Among these, 1,2-benzothiazine 1,1-dioxide nucleus has got considerable attention after the discovery of 4-hydroxy-2-methyl-2H-1,2-benzothiazine-3-carboxamides 1,1-dioxides (known as oxicams) as potent anti-inflammatory and analgesic agents.

On the other hand, 1-arylpiperazines represent a potentially biologically active moiety of heterocyclic compounds. They have been studied as $5-\mathrm{HT}_{1 \mathrm{~A}}, 5-\mathrm{HT}_{2 \mathrm{~A}}, 5-\mathrm{HT}_{2 \mathrm{C}}, 5-\mathrm{HT}_{3}$, $5-\mathrm{HT}_{4}, 5-\mathrm{HT}_{7}$ receptors ligands [8-11], $\alpha_{1}$-adrenoreceptor antagonists [12] or $\mathrm{D}_{2}, \mathrm{D}_{3}, \mathrm{D}_{4}$ receptors ligands [13-15]. Some of the well-known antipsychotic drugs that contain 1-arylpiperazine moiety are already available in the market like buspirone [16], gepirone or ipsapirone [17].

Currently, much research and development is being focused on the discovery of highly selective dopamine $\mathrm{D}_{4}$ receptor ligands. The reason for the interest in this area derives from the possible involvement of $\mathrm{D}_{4}$ receptor in schizophrenia, Parkinson's disease, bipolar disorder, additive behaviours, eating disorders such as anorexia nervosa, bulimia nervosa, binge eating or sexual disorders.

Keeping in view biological activity of benzothiazines in Alzheimers and Parkinsons diseases and $\mathrm{D}_{4}$ receptors as potentially target to 1-arylpiperazine derivatives, it was perceived that synergism of these two bioactive heterocycles may result in new molecules with accelerated activities.

For this purpose, as continuation our previous investigation on 1,2-benzothiazine derivatives, we have synthesized a series of novel 3-substituted-2H-2-\{[3-(4-phenyl)-1-piperazinyl]-propyl -4-hydroxy-1,2-benzothiazine 1,1-dioxides.

This new 1,2-benzothiazine 1,1-dioxide derivatives have some structural similarities with other $\mathrm{D}_{4}$ full or partial agonist like: WAY-100635 [18], A-412997 [19, 20], FAUC-316 and FAUC-299, ABT-724 and ABT-670 [21], which are in pharmacological screening tests. 
On other hand solid form diversity of pharmaceutical substances may influence the efficacy and safety of drug products. Physical and chemical characterization of different solid phases that may occur during crystallization and pharmaceutical formulation processes, i.e. polymorphs, pseudopolymorphism, solvates, desolvated solvates and amorphous materials are advisable for both drugs and excipients. It is very important to control the crystal form of the drug during the various stages of drug development, because any phase changes and change in the degree of crystallinity can alter the bioavailability of the drug. Thermal analysis is one of the most frequently used instrumental techniques on pharmaceutical researches [22-31].

\section{Experimental}

Synthesis

Reagents and solvents were purchased from commercial suppliers and used as received. Dry solvent was obtained according to the standard procedure. Analytical silica gel 60 $\mathrm{F}_{254}$-coated TLC plates were obtained from Fluka Chemie Gmbh and were visualized with UV light. Flash column chromatographic purifications were performed using SigmaAldrich 60A silica gel 230-400 mesh. The proton nuclear magnetic resonance $\left({ }^{1} \mathrm{H} \mathrm{NMR}\right)$ spectra were measured on a Brucker $300 \mathrm{MHz}$ NMR spectrometer. The samples were prepared by dissolving $5 \mathrm{mg}$ of each form in $600 \mu \mathrm{l}$ of $\mathrm{CDCl}_{3}$. Melting points were recorded using MEL-TEMP capillary melting point apparatus and were uncorrected. Elemental analyses were performed by Carlo Erba NA 1500 analyser and were within $\pm 0.4 \%$ of the theoretical value. FTIR spectra were run on a Perkin-Elmer spectrum two UATR FT-IR spectrometer. The samples were applied as solids.

General procedure for the preparation of 2-[3-(4-phenyl-1piperazinyl)propyl]-3-(4-substituted-benzoyl)-4-hydroxy2H-1,2-benzothiazine 1,1-dioxide derivatives

(Fig. 1, Scheme 1)

Procedure A. 2-(4-substituted-phenacyl)-2H-benzisothiazol3-on 1,1-dioxides A mixture of commercially available saccharine $(0.92 \mathrm{~g}, 5 \mathrm{mmol})$ with $5 \mathrm{mmol}$ of corresponding 2-bromoacetophenone $\mathbf{2 a - 2 d}$ [2-bromoacetophenone for obtaining 3a, 2-bromo-4'-methoxyacetophenone (3b), 2-bromo-4'-fluoroacetophenone (3c) and 2,4'-dibromoacetophenone (3d)] in $7 \mathrm{~mL}$ of $N, N$-dimethylformamide (DMF) and triethylamine $(0.7 \mathrm{~mL}, 5 \mathrm{mmol})$ was stirred at room temperature for $10 \mathrm{~h}$, then poured over ice cooled water $(50 \mathrm{~mL})$ resulted in the formation of a white solid, which was filtered and washed with cold water. The solid was dried and recrystallized from ethanol to give 2-(4substituted-phenacyl)-2H-benzisothiazol-3-on 1,1-dioxides with 88.7-98.7\% yield;

3a: Anal. $\mathrm{C}_{15} \mathrm{H}_{11} \mathrm{NO}_{4} \mathrm{~S}$ (m.w. 301.32); m.p. 472-474 K (EtOH). ${ }^{1} \mathrm{H}$ NMR $\delta: 5.15 \mathrm{~s}\left(2 \mathrm{H}, \mathrm{CH}_{2}\right), 7.49-7.97 \mathrm{~m}(9 \mathrm{H}, \mathrm{ArH})$. FT-IR: 1,739 and 1,694 (CO), 1,335 and 1,181 $\left(\mathrm{SO}_{2}\right) \mathrm{cm}^{-1}$.

3b: Anal. $\mathrm{C}_{16} \mathrm{H}_{13} \mathrm{NO}_{5} \mathrm{~S}$ (m.w. 331.34); m.p. 434-436 K $(\mathrm{EtOH}) .{ }^{1} \mathrm{H}$ NMR $\delta: 3.89 \mathrm{~s}\left(3 \mathrm{H}, \mathrm{OCH}_{3}\right), 5.11 \mathrm{~s}\left(2 \mathrm{H}, \mathrm{CH}_{2}\right)$, 6.96-7.97 $\mathrm{m}$ (8H, ArH). FT-IR: 1,738 and 1,693 (CO), 1,330 and $1,183\left(\mathrm{SO}_{2}\right) \mathrm{cm}^{-1}$.

3c: Anal. $\mathrm{C}_{15} \mathrm{H}_{10} \mathrm{FNO}_{4} \mathrm{~S}$ (m.w. 319.31); m.p. 438-441 K (EtOH). ${ }^{1} \mathrm{H}$ NMR $\delta: 5.11 \mathrm{~s}\left(2 \mathrm{H}, \mathrm{CH}_{2}\right), 7.16-8.01 \mathrm{~m}(8 \mathrm{H}, \mathrm{ArH})$. FT-IR: 1,738 and 1,693 (CO), 1,330 and 1,183 $\left(\mathrm{SO}_{2}\right) \mathrm{cm}^{-1}$.

3d: Anal. $\mathrm{C}_{15} \mathrm{H}_{10} \mathrm{BrNO}_{4} \mathrm{~S}$ (m.w. 380.21); m.p. 462-464 K (EtOH). ${ }^{1} \mathrm{H}$ NMR $\delta: 5.10 \mathrm{~s}\left(2 \mathrm{H}, \mathrm{CH}_{2}\right), 7.66-7.94 \mathrm{~m}(8 \mathrm{H}, \mathrm{ArH})$. FT-IR: 1,733 and 1,703 (CO), 1,328 and $1,179\left(\mathrm{SO}_{2}\right) \mathrm{cm}^{-1}$.

Procedure B. Rearrangement of benzisothiazolones $\mathbf{3 a - 3 d}$ to the corresponding derivatives of 3-(4-substituted-benzoyl)-4-hydroxy-2H-1,2-benzothiazines Three millimoles of corresponding benzisothiazolone 1,1-dioxide 3a-3d (3a for obtaining $\mathbf{4 a}, \mathbf{3 b}$ for $\mathbf{4 b}, \mathbf{3 c}$ for $\mathbf{4 c}$ and $\mathbf{3 d}$ for $\mathbf{4 d}$ ) were dissolved in $7.5 \mathrm{~mL}$ sodium ethoxide $(2.3 \%)$ at $313 \mathrm{~K}{ }^{\circ} \mathrm{C}$ and stirred with heating to $328-333 \mathrm{~K}$ for 5-10 min. Colour changes from beige to deep red were observed. After this time and dissolving all of the substance, the mixture was rapidly cooled to $298 \mathrm{~K}$ and $7.5 \mathrm{~mL} \mathrm{HCl} \mathrm{(9 \% )} \mathrm{was}$ added. Colour changed from deep red to deep yellow and the product precipitated. The solid was filtered off, washed with cold water, dried and purified by crystallization from EtOH to give 4a-4d with 83.5-86.4\% yield.

4a: Anal. $\mathrm{C}_{15} \mathrm{H}_{11} \mathrm{NO}_{4} \mathrm{~S}$ (m.w. 301.32); m.p. 434-436 K $(\mathrm{EtOH}) .{ }^{1} \mathrm{H}$ NMR $\delta$ : $6.07 \mathrm{~s}(1 \mathrm{H}, \mathrm{NH}), 7.44-8.23 \mathrm{~m}(9 \mathrm{H}$, ArH), 15.71 s (1H, OH enolic); FT-IR: 3,262 (NH), 1,594 $[\mathrm{C}(\mathrm{OH})=\mathrm{C}-\mathrm{C}(\mathrm{O})], 1,301$ and $1,176\left(\mathrm{SO}_{2}\right) \mathrm{cm}^{-1}$.

4b: Anal. $\mathrm{C}_{16} \mathrm{H}_{13} \mathrm{NO}_{5} \mathrm{~S}$ (m.w. 331.34); m.p. 450-452 K $(\mathrm{EtOH}) .{ }^{1} \mathrm{H}$ NMR $\delta: 3.90 \mathrm{~s}\left(3 \mathrm{H}, \mathrm{OCH}_{3}\right), 6.06 \mathrm{~s}(1 \mathrm{H}, \mathrm{NH})$, 7.27-8.21 m (8H, ArH), $16.02 \mathrm{~s}(1 \mathrm{H}, \mathrm{OH}$ enolic). FT-IR: $3,258(\mathrm{NH}), 1,597[\mathrm{C}(\mathrm{OH})=\mathrm{C}-\mathrm{C}(\mathrm{O})], 1,310$ and 1,179 $\left(\mathrm{SO}_{2}\right) \mathrm{cm}^{-1}$.

4c: Anal. $\mathrm{C}_{15} \mathrm{H}_{10} \mathrm{FNO}_{4} \mathrm{~S}$ (m.w. 319.31); m.p. 466-468 K (EtOH). ${ }^{1} \mathrm{H}$ NMR $\delta: 5.91 \mathrm{~s}(1 \mathrm{H}, \mathrm{NH}), 7.13-8.20 \mathrm{~m}(8 \mathrm{H}$, ArH), $15.80 \mathrm{~s}$ (1H, OH enolic). FT-IR: 3,151 (NH), 1,590 $[\mathrm{C}(\mathrm{OH})=\mathrm{C}-\mathrm{C}(\mathrm{O})], 1,280$ and 1,158 $\left(\mathrm{SO}_{2}\right) \mathrm{cm}^{-1}$.

4d: Anal. $\mathrm{C}_{15} \mathrm{H}_{10} \mathrm{BrNO}_{4} \mathrm{~S}$ (m.w. 380.21); m.p. 511-514 K (EtOH). ${ }^{1} \mathrm{HNMR} \delta: 6.17 \mathrm{~s}(1 \mathrm{H}, \mathrm{NH}), 7.27-8.26 \mathrm{~m}(8 \mathrm{H}, \mathrm{ArH})$, $15.73 \mathrm{~s}$ (1H, OH enolic). FT-IR: 3,225 (NH), 1,583 $[\mathrm{C}(\mathrm{OH})=\mathrm{C}-\mathrm{C}(\mathrm{O})], 1,287$ and $1,179\left(\mathrm{SO}_{2}\right) \mathrm{cm}^{-1}$.

Procedure C. 1-(3-chloropropyl)-4-phenylpiperazine (Fig. 1, Scheme 2) A commercially available 1-phenylpiperazine (6.48 g, $40 \mathrm{mmol}$ ) and 1-bromo-3-chloropropane (4.4 $\mathrm{mL}, 44 \mathrm{mmol})$ were dissolved in acetone $(12 \mathrm{~mL})$ with 
Fig. 1 Scheme for the preparation of 2-[3-(4-phenyl-1piperazinyl)propyl]-3-(4substituted-benzoyl)-4-hydroxy2H-1,2-benzothiazine 1,1-dioxide derivatives

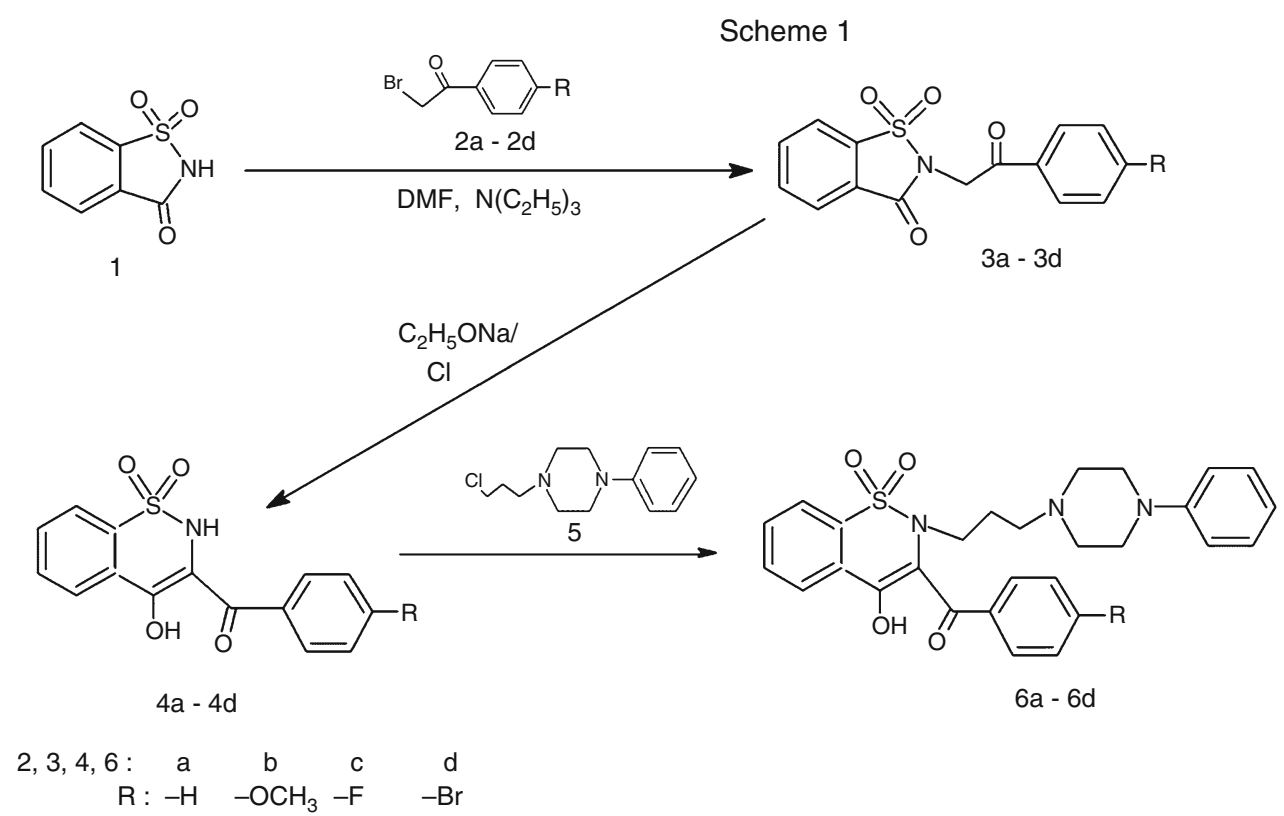

Scheme 2
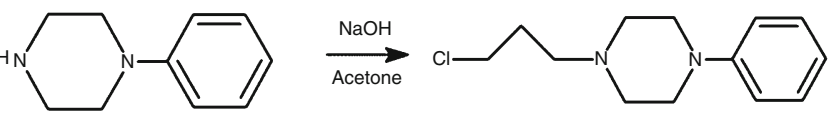

addition of $25 \% \mathrm{NaOH}(7 \mathrm{~mL})$, stirred slowly in room temperature for $8 \mathrm{~h}$ and left overnight. After this time ether $(80 \mathrm{~mL})$ was added and stirred further for $30 \mathrm{~min}$. Then, the mixture was divided in a funnel into two parts. The ether part was dried with $\mathrm{MgSO}_{4}$ and evaporated in vacuum. The residue was purified by flash silica gel chromatography, eluting with EtOAc to give $7.62 \mathrm{~g} \mathrm{(79.8 \% )} \mathrm{a} \mathrm{pale} \mathrm{yellow} \mathrm{oil} \mathrm{of} \mathrm{1-(3-}$ chloropropyl)-4-phenylpiperazine 5; Anal. $\mathrm{C}_{13} \mathrm{H}_{19} \mathrm{ClN}_{2}$ (m.w. 238.76); ${ }^{1} \mathrm{HNMR} \delta$ : 1.95-2.09 m (2H, $\left.\mathrm{CH}_{2} \mathbf{C H}_{2} \mathrm{CH}_{2}\right)$, 2.53-2.70 m [6H, $\left.\mathrm{CH}_{2} \mathrm{~N}\left(\mathrm{CH}_{2}\right)_{2}\right], \quad 3.19-3.22 \mathrm{~m} \quad[4 \mathrm{H}$, $\left.\mathrm{N}\left(\mathrm{CH}_{2}\right)_{2}\right], 3.61-3.65$ t $\left(2 \mathrm{H}, \mathbf{C H}_{2} \mathrm{CH}_{2} \mathrm{CH}_{2} \mathrm{~N}\right.$-piperazine, $J=6 \mathrm{~Hz}), 6.84-7.27 \mathrm{~m}(5 \mathrm{H}, \mathrm{ArH})$.

Procedure D. 3-(4-substituted-benzoyl)-2-[3-(4-phenyl1-piperazinyl)propyl]-4-hydroxy-2H-1,2-benzothiazine 1, 1-dioxide derivatives To the stirred mixture of $5 \mathrm{mmol}$ of corresponding 1,2-benzothiazine $\mathbf{4 a - 4 d}$ in $20 \mathrm{~mL}$ of anhydrous EtOH was added $5 \mathrm{~mL}$ of EtONa (prepared from $0.115 \mathrm{~g}$ of $\mathrm{Na}$ and $5 \mathrm{~mL}$ of anhydrous EtOH). Then, $5 \mathrm{mmol}$ of 1-(3-chloropropyl)-4-phenylpiperazine 5 was added and refluxed with stirring for 10-12 $\mathrm{h}$. When the reaction was ended, which was controlled on TLC plates, ethanol was distiled off, the residue was treated with $50 \mathrm{~mL}$ of $\mathrm{CHCl}_{3}$ and insoluble materials were filtered off. The filtrate was then evaporated and the residue was purified by crystallization from ethanol to give 6a-6d (yield: 34.0-54.0 \%).

2-[3-(4-phenyl-1-piperazinyl)propyl]-3-benzoyl-4-hydroxy2H-1,2-benzothiazine 1,1-dioxide (6a). Anal. $\mathrm{C}_{28} \mathrm{H}_{29} \mathrm{~N}_{3} \mathrm{O}_{4} \mathrm{~S}$ (m.w. 503.61); m.p. 440-443 K (EtOH). ${ }^{1} \mathrm{H}$ NMR $\delta$ : 1.21-1.26 m (2H, $\left.\mathrm{CH}_{2} \mathbf{C H}_{2} \mathrm{CH}_{2}\right), 1.94-1.99 \mathrm{~m}\left(2 \mathrm{H}, \mathbf{C H}_{2} \mathrm{CH}_{2}\right.$ $\mathrm{CH}_{2} \mathrm{~N}$-piperazine), $2.21-2.28 \mathrm{~m}\left[4 \mathrm{H}, \mathrm{N}\left(\mathrm{CH}_{2}\right)_{2}\right], 3.01-3.27 \mathrm{~m}$ $\left[6 \mathrm{H}, \mathrm{CH}_{2} \mathrm{~N}\left(\mathrm{CH}_{2}\right)_{2}\right], 6.82-8.22 \mathrm{~m}(14 \mathrm{H}, \mathrm{ArH}), 15.71 \mathrm{~s}(1 \mathrm{H}, \mathrm{OH}$ enolic); FT-IR: 1,598, 1,611 [C(OH) $=\mathrm{C}-\mathrm{C}(\mathrm{O})], 1,331$ and 1,173 $\left(\mathrm{SO}_{2}\right) \mathrm{cm}^{-1}$; Anal. Calcd: C, 66.78; H, 5.80; N, 8.34. Found: C, 66.66; H, 5.94; N, 8.39.

2-[3-(4-phenyl-1-piperazinyl)propyl]-3-(4-methoxybenzoyl)-4-hydroxy-2H-1,2-benzothiazine 1,1-dioxide (6b). Anal. $\mathrm{C}_{29} \mathrm{H}_{31} \mathrm{~N}_{3} \mathrm{O}_{5} \mathrm{~S}$ (m.w. 533.64); m.p. $388-391 \mathrm{~K}$ (EtOH). ${ }^{1} \mathrm{H}$ NMR $\delta: 1.22-1.31 \mathrm{~m}\left(2 \mathrm{H}, \mathrm{CH}_{2} \mathbf{C H}_{2} \mathrm{CH}_{2}\right)$, 1.96-1.98 m (2H, $\mathbf{C H}_{2} \mathrm{CH}_{2} \mathrm{CH}_{2} \mathrm{~N}$-piperazine), 2.24-2.30 m [4H, N( $\left.\left(\mathrm{CH}_{2}\right)_{2}\right], 3.01-3.35 \mathrm{~m}\left[6 \mathrm{H}, \mathrm{CH}_{2} \mathrm{~N}\left(\mathrm{CH}_{2}\right)_{2}\right], 3.90 \mathrm{~s}(3 \mathrm{H}$, $\left.\mathrm{OCH}_{3}\right), 6.85-8.20 \mathrm{~m}(13 \mathrm{H}, \mathrm{ArH}), 15.76 \mathrm{~s}(1 \mathrm{H}, \mathrm{OH}$ enolic $)$; FT-IR: $1,599,1,612[\mathrm{C}(\mathrm{OH})=\mathrm{C}-\mathrm{C}(\mathrm{O})], 1,318$ and 1,173 $\left(\mathrm{SO}_{2}\right) \mathrm{cm}^{-1}$; Anal. Calcd: C, 65.24; H, 5.85; N, 7.91. Found: C, 65.54; H, 5.90; N, 8.00.

2-[3-(4-phenyl-1-piperazinyl)propyl]-3-(4-fluorobenzoyl)4-hydroxy-2H-1,2-benzothiazine 1,1-dioxide (6c). Anal. $\mathrm{C}_{28} \mathrm{H}_{28} \mathrm{FN}_{3} \mathrm{O}_{4} \mathrm{~S}$ (m.w. 521.60); m.p. 376-378 K (EtOH). ${ }^{1} \mathrm{H}$ NMR $\delta$ : $1.21-1.26 \mathrm{~m}\left(2 \mathrm{H}, \mathrm{CH}_{2} \mathbf{C H}_{2} \mathrm{CH}_{2}\right), 1.95-2.00 \mathrm{~m}(2 \mathrm{H}$,

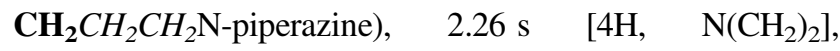
3.04-3.30 m [6H, $\left.\mathrm{CH}_{2} \mathrm{~N}\left(\mathrm{CH}_{2}\right)_{2}\right], 6.82-8.20 \mathrm{~m}(13 \mathrm{H}, \mathrm{ArH})$, $15.50 \mathrm{~s}(1 \mathrm{H}, \mathrm{OH}$ enolic $)$; FT-IR: 1,597, 1,609 [C(OH)= $\mathrm{C}-\mathrm{C}(\mathrm{O})], 1,333$ and $1,174\left(\mathrm{SO}_{2}\right) \mathrm{cm}^{-1}$; Anal. Calcd: $\mathrm{C}$, 64.47; H, 5.41; N, 8.06. Found: C, 64.35; H, 5.44; N, 8.02.

2-[3-(4-phenyl-1-piperazinyl)propyl]-3-(4-bromobenzoyl)4-hydroxy-2H-1,2-benzothiazine 1,1-dioxide (6d). Anal. $\mathrm{C}_{28} \mathrm{H}_{28}$ 
$\mathrm{BrN}_{3} \mathrm{O}_{4} \mathrm{~S}$ (m.w. 582.51); m.p. 374-377 K (EtOH). ${ }^{1} \mathrm{H}$ NMR $\delta: 1.22-1.26 \mathrm{~m}\left(2 \mathrm{H}, \mathrm{CH}_{2} \mathbf{C H}_{2} \mathrm{CH}_{2}\right), 1.97-2.07 \mathrm{~m}(2 \mathrm{H}$, $\mathrm{CH}_{2} \mathrm{CH}_{2} \mathrm{CH}_{2} \mathrm{~N}$-piperazine), 2.24-2.34 m [4H, N( $\left.\mathrm{CH}_{2}\right)_{2}$ ], 3.03-3.31 m [6H, $\left.\mathrm{CH}_{2} \mathrm{~N}\left(\mathrm{CH}_{2}\right)_{2}\right], 6.86-8.19 \mathrm{~m}(13 \mathrm{H}, \mathrm{ArH})$, $15.70 \mathrm{~s}(1 \mathrm{H}, \mathrm{OH}$ enolic $)$; FT-IR: 1,599, 1,610 [C(OH) $=\mathrm{C}-\mathrm{C}(\mathrm{O})], 1,328$ and $1,173\left(\mathrm{SO}_{2}\right) \mathrm{cm}^{-1} ;$ Anal. Calcd: $\mathrm{C}$, 57.71; H, 4.84; N, 7.24. Found: C, 57.32; H, 4.85; N, 7.22

Differential thermal analysis

The DSC traces were recorded on a Mettler Toledo DCS 25 measuring cell with TC15TA Controller, calibrated with indium to ensure the accuracy of the calorimetric scale. Samples weighing 6-10 mg (crystals form) were characterized in sealed $40 \mu \mathrm{l}$ aluminium pans with lids and subjected to thermal analysis under a flowing argon atmosphere $\left(30 \mathrm{~cm}^{3} \mathrm{~min}^{-1}\right)$. Analysis was carried out from $303 \mathrm{~K}$ using heating rate $5 \mathrm{~K} \mathrm{~min}^{-1}$ (additionally 1 and $10 \mathrm{~K} \mathrm{~min}^{-1}$ ) with an identical empty sample pan as reference. For each compound several measurements were performed. Melting temperatures were determined by the onset because the onset temperature is independent of sample mass and scanning rate. Pans with lids and samples were weighed both before and after the experiment. In all cases, the mass was identical.

\section{Computational methods}

The primary task for the computational work was to determine the optimized geometry of the compounds.
Calculations were carried out using the GAUSSIAN 09 software package [32]. Density functional theoretical (DFT) computations were performed using the closed shell Becke-Lee-Yang-Parr hybrid exchange-correlation threeparameter functional (B3LYP) [33-35] in combination with $6-311+G(d, p)$ basis set. Harmonic vibrational wavenumbers were calculated using analytic second derivatives to confirm the convergence to minima in the potential surface. The absence of imaginary frequency modes for the optimized structures confirm a true minimum on the potential energy surface. All calculations were carried out in vacuum.

\section{Results and discussion}

The DSC scans for benzisothiazolones $\mathbf{3 a - 3 d}$ are shown in Fig. 2. For all compounds only one endothermic effect, corresponds to the melting, is observed. The melting points were found as $470 \mathrm{~K}(\mathbf{3 a}), 440 \mathrm{~K}(\mathbf{3 b}), 439 \mathrm{~K}(\mathbf{3 c}), 466 \mathrm{~K}$ (3d). The peaks are sharp and symmetrical, characteristic for a pure substance.

The DSC scans for derivatives of 3-(4-substituted-benzoyl)-4-hydroxy-2H-1,2-benzothiazines $\mathbf{4 a - 4 d}$ are given in Fig. 3. For compound 4a two endothermic effects were detected. The DSC signal starts to fall below the baseline at $428 \mathrm{~K}$. The second peak is symmetrical. The onset temperature is $428 \mathrm{~K}$. For compound $\mathbf{4 b}$ the DSC trace shows a wide endothermic effect with a small bend at $452 \mathrm{~K}$. For compound $\mathbf{4 c}$ and $\mathbf{4 d}$ one endothermic effect is recorded.
Fig. 2 DSC curves for compounds $\mathbf{3 a}-\mathbf{3 d}$ heated at $5 \mathrm{~K} \mathrm{~min}^{-1}$

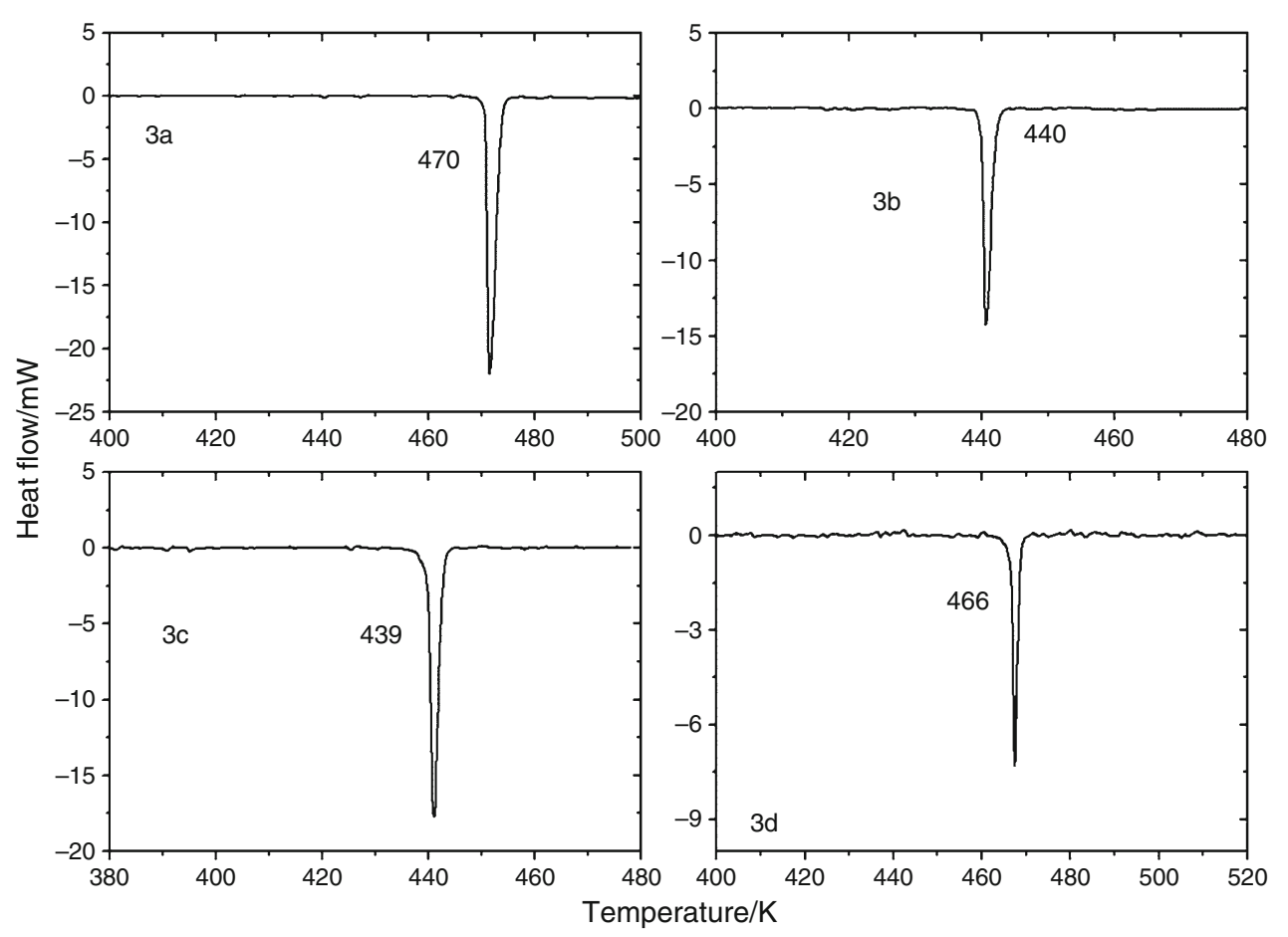


Fig. 3 DSC curves for compounds $\mathbf{4 a}-\mathbf{4 d}$ heated at $5 \mathrm{~K} \mathrm{~min}^{-1}$ (solid line) and deconvolved signal (dash line)

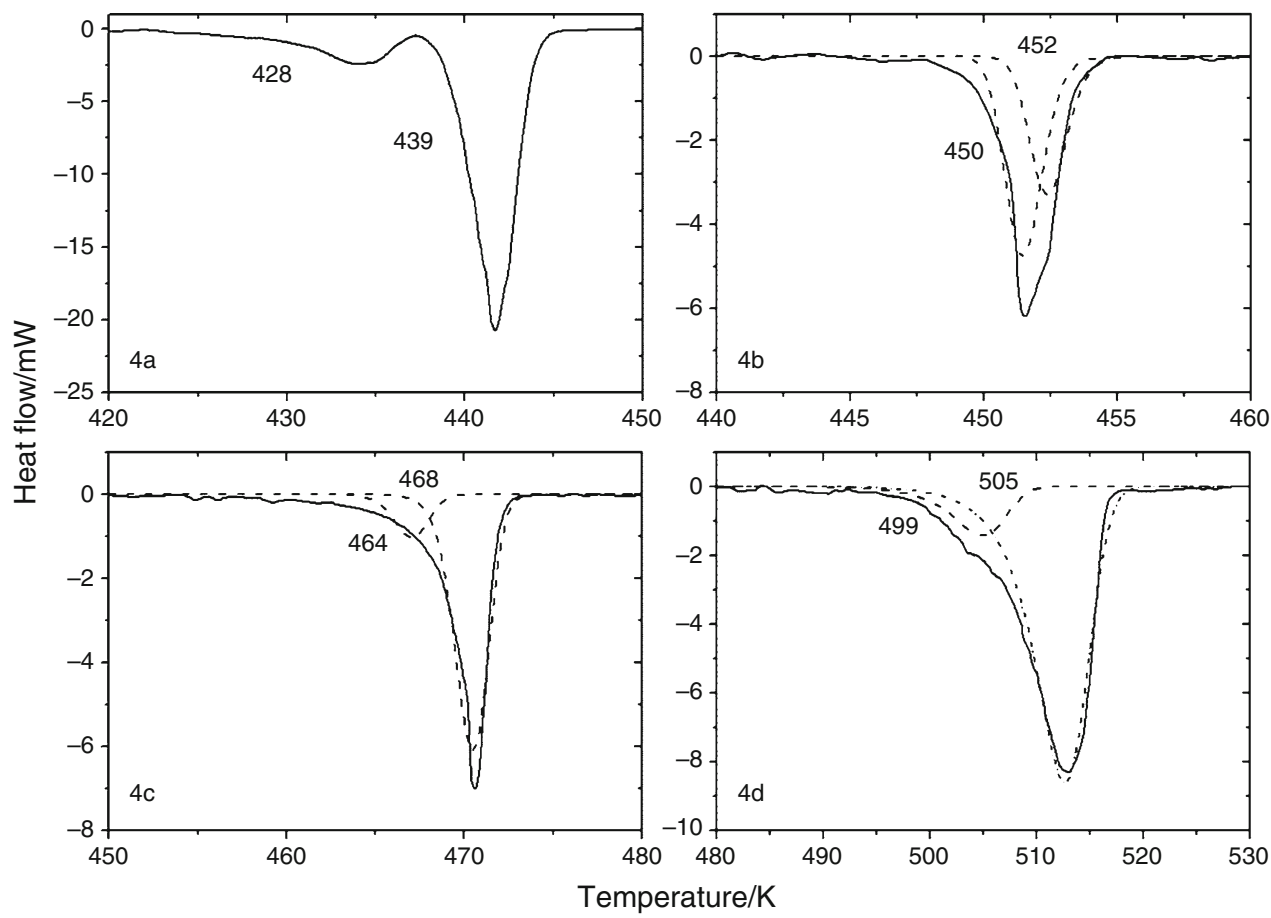

The peak is wide and asymmetric. For compound $\mathbf{4 c}$ signal starts to fall below the baseline at $460 \mathrm{~K}$ and then rapidly at $460 \mathrm{~K}$. For compound 4d a small bend at $504 \mathrm{~K}$ is observed. For these substances, DSC runs show the presence of overlapping peaks, corresponding probably to two thermal events, close to each other. In order to determine the overlapping peak positions and areas, a curve fitting analysis for DSC curves was carried out. Deconvolved signal was calculated using Exponentially Modified
Gaussian function (EMG, $r^{2}=0.991,0.973,0.982$ for $\mathbf{4 b}$, $\mathbf{4 c}, \mathbf{4 d}$, respectively). As a result two separate peaks were obtained (Fig. 3). The onset temperatures are: 450 and $453 \mathrm{~K}$ for $\mathbf{4 b}, 464$ and $468 \mathrm{~K}$ for $\mathbf{4 c}, 499$ and $505 \mathrm{~K}$ for $\mathbf{4 d}$.

The DSC scans for 3-(4-substituted-benzoyl)-2-[3-(4phenyl-1-piperazinyl)propyl]-4-hydroxy-2H-1,2-benzothiazine 1,1-dioxide derivatives 6a-6d are presented in Fig. 4. For compound $\mathbf{6 a}$, the DSC trace shows a wide endothermic effect with a small bend at $434 \mathrm{~K}$. After deconvolved
Fig. 4 DSC curves for compounds 6a-6d heated at $5 \mathrm{~K} \mathrm{~min}^{-1}$ (solid line) and deconvolved signal (dash line)
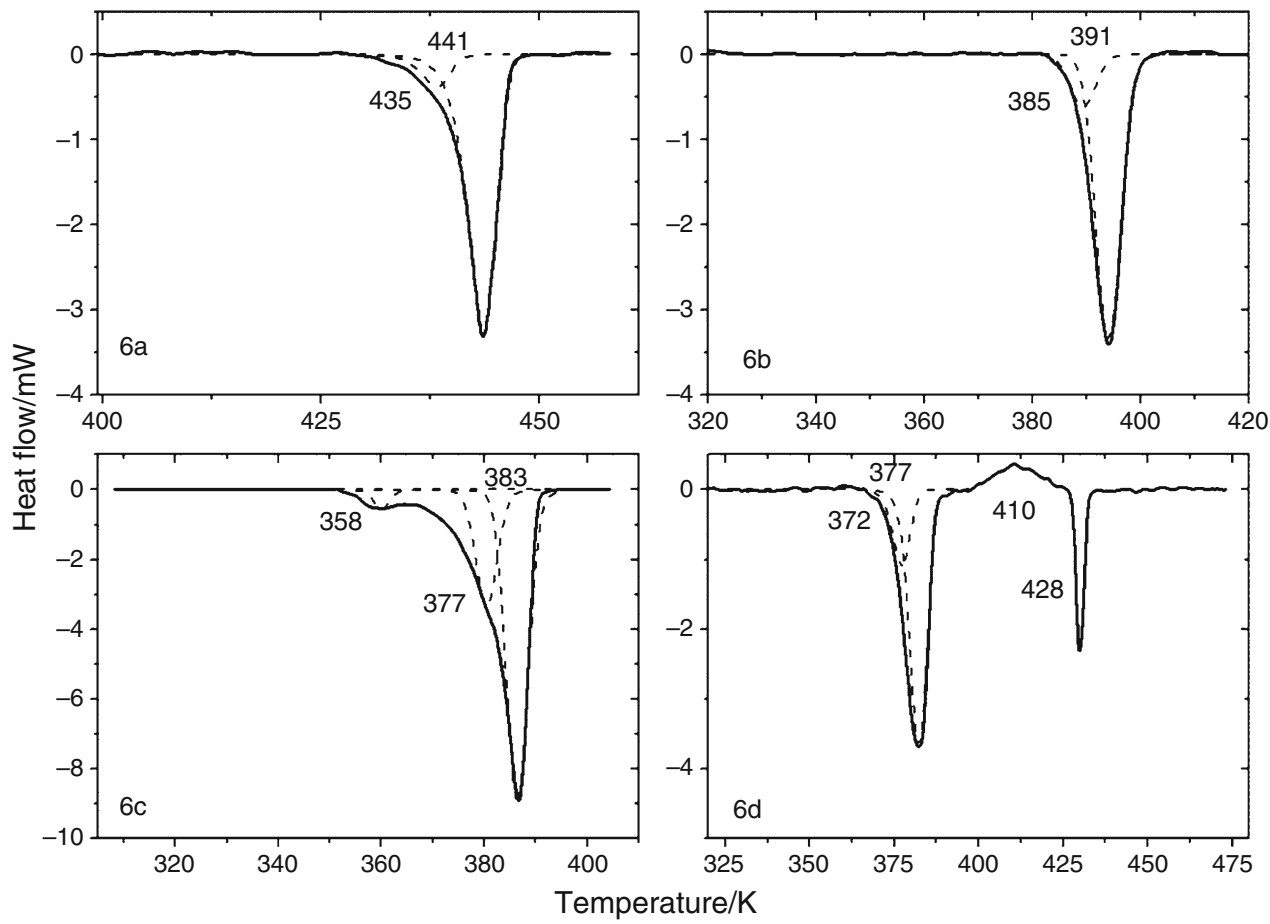
Fig. 5 Three possible tautomeric forms in crystals 2-[3-(4-phenyl-1-

piperazinyl)propyl]-3-(4substituted-benzoyl)-4-hydroxy2H-1,2-benzothiazine 1,1dioxides (compound 6a-6d): $O$-enol $/ O$-keto, $O$-keto/ $O$-enol and $O$-keto/O-keto/CH2

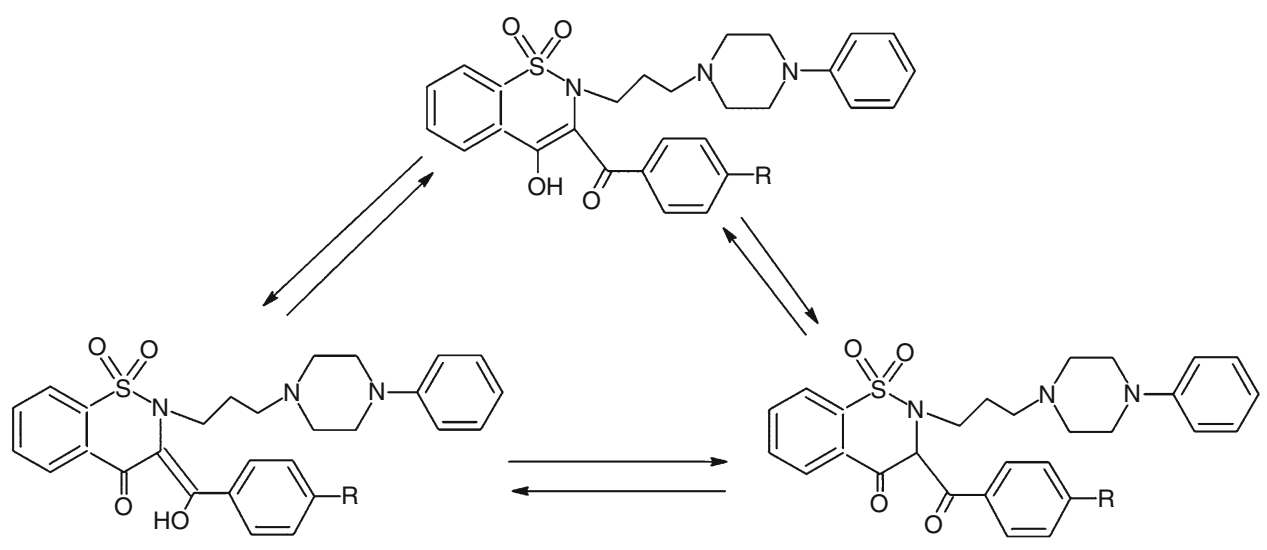

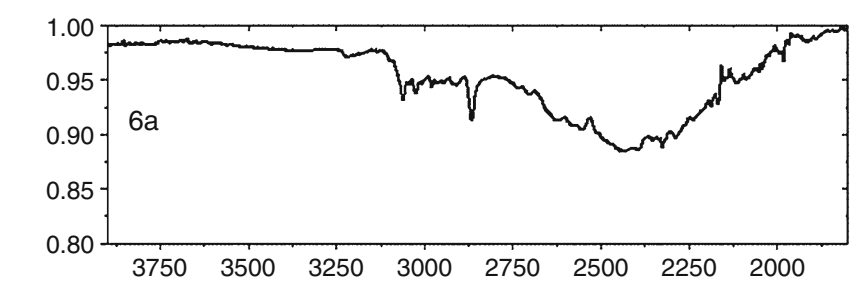
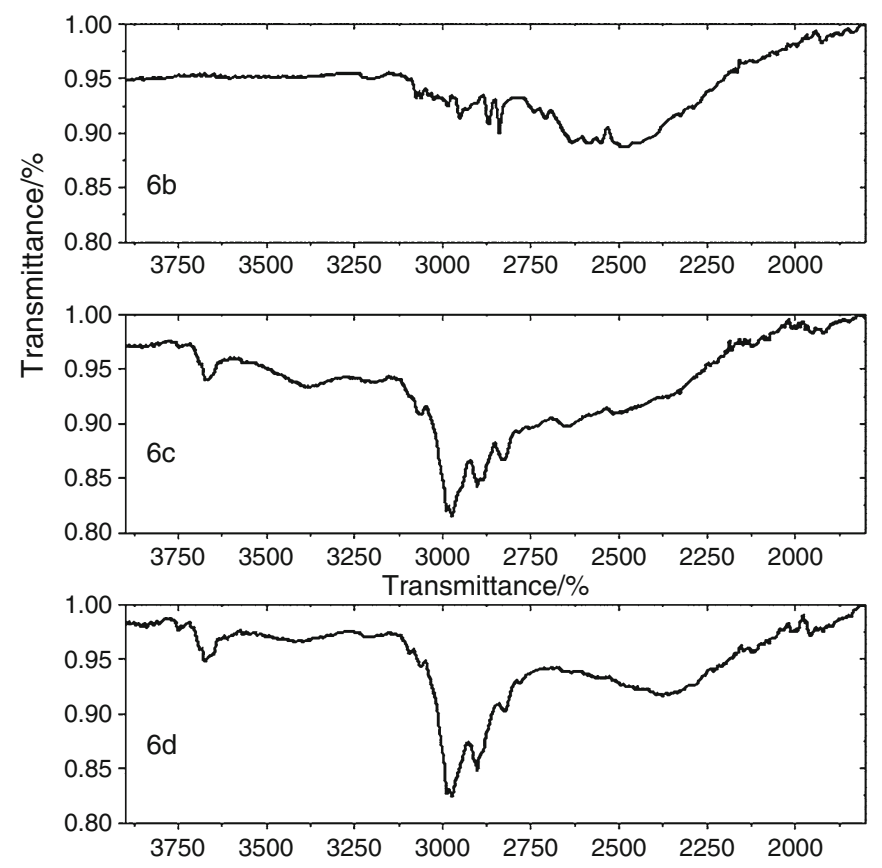
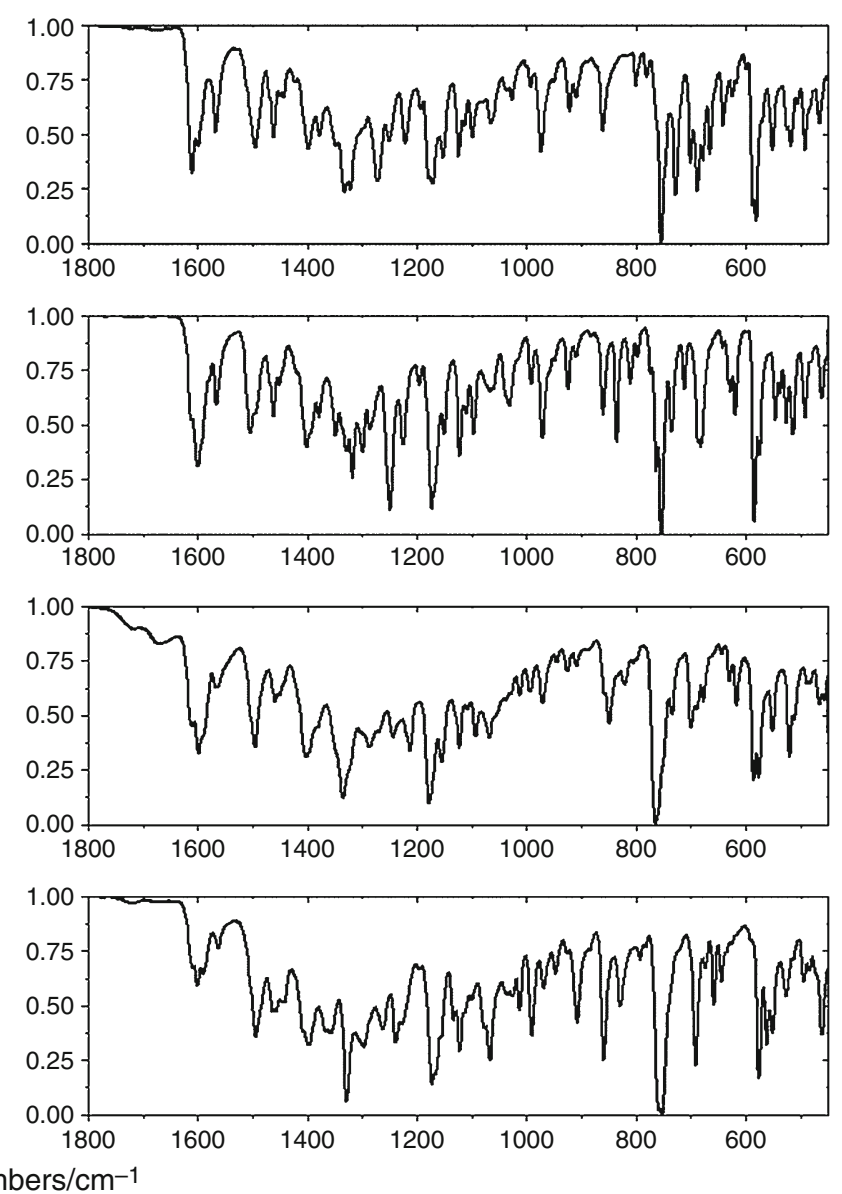

Fig. 6 Experimental FTIR spectrum for compounds $\mathbf{6 a - 6 d}$

two separate peaks were obtained. The onset temperatures are: 435 and $441 \mathrm{~K}\left(r^{2}=0.997\right)$. For compound $\mathbf{6 b}$ one endothermic effect was detected. It is wide, with a small step at temperature $385 \mathrm{~K}$. This effect is better to observe on the curves with scanning rate $10 \mathrm{~K} \mathrm{~min}^{-1}$. The onset temperatures after deconvolved are 385 and $391 \mathrm{~K}$ $\left(r^{2}=0.999\right)$. Two endothermic effects were observed during heating substance 6c. The first with maximum at $359 \mathrm{~K}$ starts at $352 \mathrm{~K}$. The second one is wide and asymmetric. This effect shows the presence of overlapping peaks, corresponding to two thermal events. The onset temperatures after deconvolved are 377 and $383 \mathrm{~K}$ $\left(r^{2}=0.971\right)$. Three thermal effects are detected heating substance 6d. Two endothermic peaks at 374 and $428 \mathrm{~K}$ and wide exothermic one. It starts at $398 \mathrm{~K}$ and end at $423 \mathrm{~K}$. The second endothermic peak is sharp and symmetrical, characteristic for melting process. The first one is wide and it seems to be the presence of overlapping peaks. 
After deconvolved two separate peaks were obtained. The onset temperatures are: 372 and $377 \mathrm{~K}\left(r^{2}=0.981\right)$.

The experiments for heating and cooling rates were also performed. In addition, second heating run, after rapid cooling, was carried out. For all experiments, thermal effects were not observed. This indicate that thermal events are irreversible. After the melting process, substances go into the amorphous state.

We suggest that the presence of overlapping peaks, close to each other, is the result of dynamic proton tautomerism in their crystal structures. Three isomers are possible: enol-keto, keto-enol and keto-keto form (Fig. 5). However, crystalline state may be stabilized by strong intermolecular $\mathrm{O}-\mathrm{H} \cdots \mathrm{O}$ hydrogen bonding and keto-keto form, probably is not present. These conditions were detected in crystal structure similar compounds: 3-[hydroxy(phenyl)methyl]-2,5,7-trimethyl2,3-dihydropyrido[3,2-e]-[1, 2] thiazin-4-one 1,1-dioxide and 3-(1-hydroxyethylidene)-2,5,7-trimethyl-2,3-dihydropyrido[3,2-e][1, 2]-thiazin-4-one 1,1-dioxide [36].

The FTIR spectra of compounds $\mathbf{6 a - 6 \mathbf { d }}$ in the solid-state is shown in Fig. 6. In the region 3,900-1,800 $\mathrm{cm}^{-1}$, only a weak and broad bands are observed. It was assigned to stretching vibration of the hydroxyl group involved in the intra- and intermolecular hydrogen bond, which is superimposed on the $\mathrm{C}-\mathrm{H}$ and $\mathrm{Ar}-\mathrm{H}$ stretching vibration. A few small maximums were detected. By comparing FTIR spectra in this region, the sharpness and intensity of bands seem to indicate that $\mathrm{H}$ bonds are not as strong in $\mathbf{6 c}$ and $\mathbf{6 d}$ as they are in $\mathbf{6 a}$ and $\mathbf{6 b}$. In addition, for substance $\mathbf{6 c}$ and $\mathbf{6 d}$, weak and broad bands at $3,380,3,670 \mathrm{~cm}^{-1}(\mathbf{6 c})$ and $3,411,3,723 \mathrm{~cm}^{-1}(\mathbf{6 d})$ were detected. This can be probably assigned to intermolecular halogen bonding (interaction). In the region 1,800-450 $\mathrm{cm}^{-1}$, FTIR spectra for $\mathbf{6 a - 6 d}$ is similar. Single stretching band characteristic for $\mathrm{C}=\mathrm{O}$ vibration is not observed. The band with a higher intensity near $1,600 \mathrm{~cm}^{-1}$. It was assigned to stretching vibration of $\mathrm{C}(\mathrm{OH})=\mathrm{C}-\mathrm{C}(\mathrm{O})$. It splits into two bands at 1,598, 1,611 $\mathrm{cm}^{-1}(\mathbf{6 a}), 1,599,1,612 \mathrm{~cm}^{-1}(\mathbf{6 b})$, $1,597,1,609 \mathrm{~cm}^{-1}$ (6c), 1,599, 1,610 $\mathrm{cm}^{-1}$ (6d) since the $\mathrm{C}=\mathrm{O}$ group is engaged in hydrogen bonding.

The main absorption bands of FTIR theoretical and experimental were compared and shown in Table 1. The calculated vibrational wavenumbers are in good agreement with the experimental data expect vibration of $\mathrm{C}(\mathrm{OH})=$ $\mathrm{C}-\mathrm{C}(\mathrm{O})$. But the calculations were performed for single molecules in the gas phase. The significant differences may indicate the hydrogen bonding in the solid-state.

Dynamic proton transfer may cause small differences in molecular packing and possibility co-existence in a crystalline state two tautomeric forms: keto-enol cannot be precluded. Thus, on the DSC curves, overlapping peaks, close to each are observed. Our theoretical calculations show small differences in the energy between both forms of $1.46-1.58 \mathrm{~kJ} \mathrm{~mol}^{-1}(\mathbf{4 a}-\mathbf{4 d})$ and $1.31-1.42 \mathrm{~kJ} \mathrm{~mol}^{-1}$

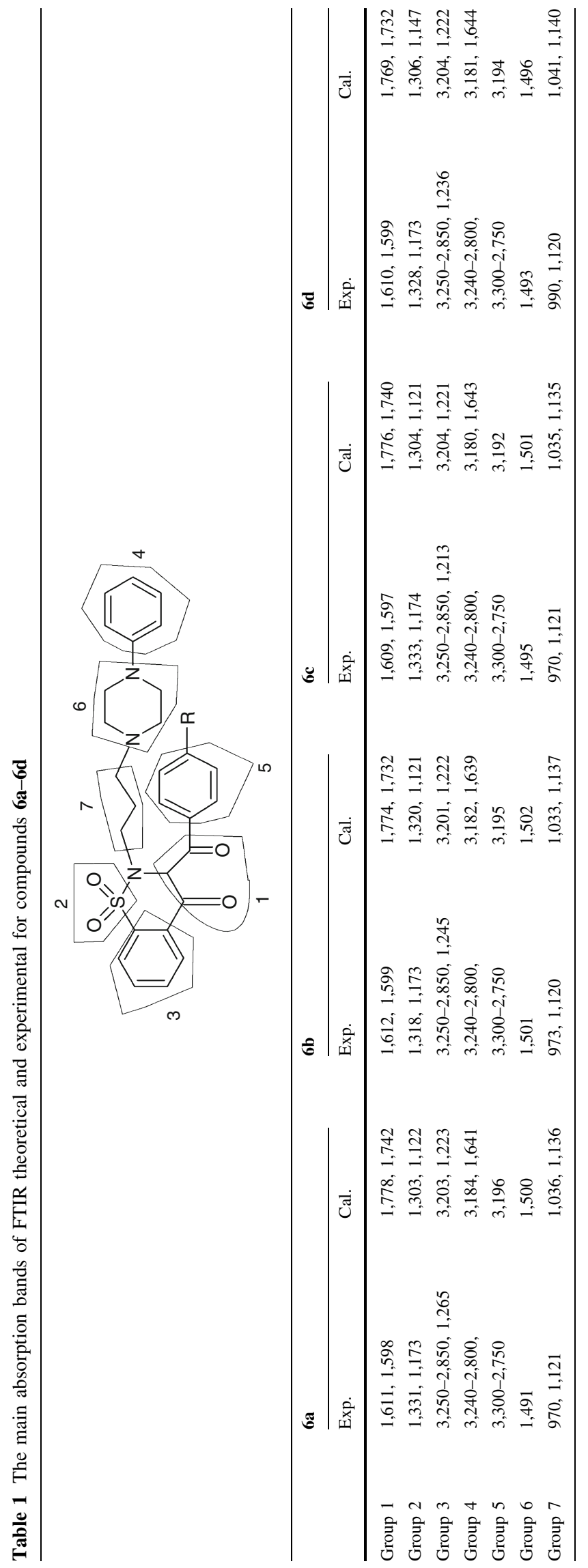




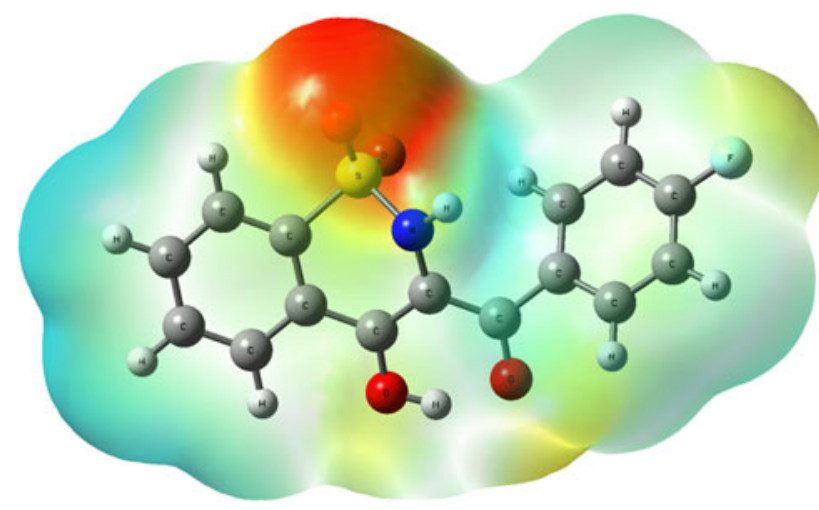

Fig. $73 \mathrm{D}$ plots of the molecular electrostatic potential map of the molecule $\mathbf{4 c}$

(6a-6d). Thus, the populations of the tautomers keto-enol in vacuum estimated using Boltzmann distribution are in the approximate ratio $0.55: 0.45$ for $\mathbf{4 a}-\mathbf{4 d}$ and 0.52:0.48 for 6a-6d. The results of theoretical calculations show also that third possible tautomeric form, keto-keto, is the most stable form. However, as already mentioned, ability to form hydrogen bonds stabilize the crystal structure.

The molecular electrostatic potential (MEP) is helpful in identifying sites for intra- and intermolecular interactions [37]. In drug-receptor, it is a very useful descriptor in understanding sites for electrophilic and nucleophilic reactions as well as hydrogen bonding interactions [38]. The calculated MEP for compound $\mathbf{4 c}$ is shown in Fig. 7. Similar results were obtained for other molecules. Negative regions (red and yellow) are found around the $\mathrm{S}=\mathrm{O}$ groups, $-\mathrm{F}$ atom in benzene ring and also close to $\mathrm{O}$ atom at $-\mathrm{OH}$ and -CO group. Our theoretical calculations for the dimer interaction through the hydrogen bond show a stabilizing effect. The energy of interaction is higher for molecule $\mathbf{6 a}$ and $\mathbf{6 b}$. Energy value obtained for molecule $\mathbf{6 c}$ and $\mathbf{6 d}$ are lower by $2 \mathrm{~kJ} \mathrm{~mol}^{-1}$. It is worth noting that the enthalpy of melting is also the highest for substance $\mathbf{6 a}$ and the lower for substance $\mathbf{6 d}$.

The DSC traces for compound $\mathbf{6 c}$ and $\mathbf{6 d}$ are different from the trace for compound $\mathbf{6 a}$ and $\mathbf{6 b}$. An additional thermal effect is observed. The presence of the $-\mathrm{Br}$ and $-\mathrm{F}$ substituent in the benzene ring causes a strong inductive effect. Electrons are withdrawn from the ring through a $\sigma$ bond. This may facilitate intermolecular $\mathrm{O}-\mathrm{H} \cdots \mathrm{F}$ bond formation. It also seems that an important factor affecting the strong of intermolecular $\mathrm{O}-\mathrm{H} \cdots \mathrm{O}-\mathrm{S}$ hydrogen bond is a propyl-4-phenylpiperazine group (spherical barrier). As a consequence, co-existence in crystalline state forms with differences in molecular packing is possible (three peaks on DSC traces for $\mathbf{6 c}$ ). On other hand a resonance effect (donation of electrons through a $\pi$ bond) increases $\pi$ electron density. It can influence the van der Waal's interactions between benzene rings. Compound $\mathbf{6 d}$ shows two melting peaks with a recrystallization step. On heating, the substance is not directly transformed from crystalline state to an isotropic melt. The second melting peak corresponds to other modification.

\section{Conclusions}

Four new 2-[3-(4-phenyl-1-piperazinyl)propyl]-3-(4-substituted-benzoyl)-4-hydroxy-2H-1,2-benzothiazine 1,1-dioxides were synthesized. The studied compounds are interesting materials due to their potential biologically active. Thermal analysis may be very useful for monitoring and identification substances during organic synthesis. In pharmaceutical industry, it is very important to control the purity of crystal form. The important aspect of our investigation was to determine the existence of multiple crystal forms. The DSC scans for all compounds show more than one endothermic effect (or overlapping peaks), which might suggest dynamic proton transfer between two or three possible tautomeric forms: $O$-keto/O-enol, $O$-enol $/ O$-keto and $O$-keto/O-keto/ $\mathrm{CH}_{2}$ in crystals 2-[3-(4-phenyl-1-piperazinyl)propyl]-3(4-substituted-benzoyl)-4-hydroxy-2H-1,2-benzothiazine 1, 1-dioxides. The study further demonstrates the utility of deconvolution software for separating overlapping DSC endotherms. Our theoretical calculations show small differences in the energy between keto-enol tautomeric forms. The FTIR spectra analysis and theoretical calculations suggest that the crystal state is stabilized by a strong intermolecular hydrogen bonding. The presence of the $-\mathrm{Br}$ and $-\mathrm{F}$ substituent in the benzene ring causes an inductive effect. As a consequence, coexistence in crystalline state forms with differences in molecular packing is possible.

Acknowledgments Calculations have been carried out in Wroclaw Centre for Networking and Supercomputing (http://www.wcss. wroc.pl).

Open Access This article is distributed under the terms of the Creative Commons Attribution License which permits any use, distribution, and reproduction in any medium, provided the original author(s) and the source are credited.

\section{References}

1. Lombardino JG, Wiseman ED. Sudoxicam and related $N$-heterocyclic carboxamides of 4-hydroxy- $2 \mathrm{H}-1$,2-benzothiazine 1 , 1-dioxide. Potent nonsteroidal anti-inflammatory agents. J Med Chem. 1972; 15:848-9.

2. Gupta SK, Bansal P, Bhardwaj RK, Jaiswal J, Velpandian T. Comparison of analgesic and anti-inflammatory activity of meloxicam gel with diclofenac and piroxicam gels in animal models: pharmacokinetic parameters after topical application. Skin Pharmacol Appl Skin Physiol. 2002;15:105-11. 
3. Ziaurrehman M, Choudary JA, Ahmad S, Siddiqui HL. Synthesis of potential biologically active 1,2-benzothiazin-3-yl-quinazolin4(3H)-ones. Chem Pharm Bull. 2006;54:1175-8.

4. Malagu K, Boustie J, David MD, Sauleau J, Amoros M, Girre R, Sauleau A. Synthesis and antiviral activity of new 1, 4-benzothiazines: sulphoxides and sulphone derivatives. Pharm Pharmacol Commun. 1998;4:57-60.

5. Gunning WT, Kramer PM, Lubet RA, Steele VE, Pereira MA. Chemoprevention of vinyl carbamate-induced lung tumors in strain A mice. Exp Lung Res. 2000;26:757-72.

6. Tawada H, Sugiyama Y, Ikeda H, Yamamoto Y, Meguro K. Studies on antidiabetic agents. IX. A new aldose reductase inhibitor, AD-5467, and related 1,4-benzoxazine and 1,4-benzothiazine derivatives: synthesis and biological activity. Chem Pharm Bull. 1990;38:1238-45.

7. Shen XM, Dryhurst G. Influence of glutathione on the oxidation chemistry of 5-S-cysteinyldopamine: potentially neuroprotective reactions of relevance to Parkinson's disease. Tetrahedron. 2001;57(2):393-405.

8. Heinrich T, Bottcher H, Gericke R, Bartoszyk GD, Anzali S, Seyfried CA, Greiner HE, Van Amsterdam C. Synthesis and structure-activity relationship in a class of indolebutylpiperazines as dual $5-\mathrm{HT}_{1 \mathrm{~A}}$ receptor agonists and serotonin reuptake inhibitors. J Med Chem. 2004;47:4684-92.

9. Seo HJ, Park E-J, Kim MJ, Kang SY, Lee SH, Kim HJ, Lee KN, Jung ME, Lee MW, Kim MS, Son EJ, Park WK, Kim J, Lee J. Design and synthesis of novel arylpiperazine derivatives containing the imidazole core targeting 5-HT2A receptor and 5-HT transporter. J Med Chem. 2011;54:6305-18.

10. Cappelli A, Anzini M, Vomero S, Mennuni L, Makovec F, Doucet E, Hamon M, Bruni G, Romeo MR, Menziani C, Benedetti PG, Langer T. Novel potent and selective central 5- $\mathrm{H}_{\mathrm{T} 3}$ receptor ligands provided with different intrinsic efficacy. 1. Mapping the central 5- $\mathrm{H}_{\mathrm{T} 3}$ receptor binding site by arylpiperazine derivatives. J Med Chem. 1998;41:728-41.

11. Vermeulen ES, Smeden M, Schmidt AW, Sprouse JS, Wikstrom HV, Grol C. Novel 5-HT 7 receptor inverse agonists. Synthesis and molecular modeling of arylpiperazine- and 1,2,3,4-tetrahydroisoquinoline-based arylsulfonamides. J Med Chem. 2004;47:5451-66.

12. Betti L, Corelli F, Floridi M, Giannaccini G, Maccari L, Manetti F, Strappaghetti G, Botta M. Structural optimization of pyridazinonearylpiperazines. Study of the influence on affinity and selectivity of cyclic substituents at the pyridazinone ring and alkoxy groups at the arylpiperazine moiety. J Med Chem. 2003;46:3555-8.

13. Wustrow DJ, Smith WJ III, Corbin AE, Davis MD, Georgic LM, Pugsley TA, Whetzel SZ, Heffner TG, Wise LD. 3-[[(4-Aryl-1piperazinyl)alkyl]cyclohexyl]-1H-indoles as dopamine $\mathrm{D}_{2}$ partial agonists and autoreceptor agonists. J Med Chem. 1997;40:250-9.

14. Leopoldo M, Berardi F, Colabufo NA, De Giorgio P, Lacivita E, Perrone R, Tortorella V. Structure-affinity relationship study on $\mathrm{N}$-[4-(4-arylpiperazin-1-yl)butyl]arylcarboxamides as potent and selective dopamine $\mathrm{D}_{3}$ receptor ligands. J Med Chem. 2002;45: 5727-35.

15. Perrone R, Berardi F, Colafubo NA, Leopoldo M, Tortorella V. 1-(2-methoxyphenyl)-4-alkylpiperazines: effect of the N-4 substituent on the affinity and selectivity for dopamine $\mathrm{D}_{4}$ receptor. Bioorganic Med Chem Lett. 1997;7:1327-30.

16. Goa KI, Ward A. Buspirone. A preliminary review of its pharmacological properties and therapeutic efficacy as an anxiolytic. Drugs. 1986;32:114-29.

17. Becker OM, Dhanoa DS, Marantz Y, Chen D, Shacham S, Cheruku S, Heifetz A, Mohanty P, Fichman M, Sharadendu A, Nudelman R, Kauffman M, Noiman S. An integrated in silico 3D model-driven discovery of a novel, potent, and selective amidosulfonamide 5-HT1A agonist (PRX-00023) for the treatment of anxiety and depression. J Med Chem. 2006;49:3116-35.
18. Chemel BR, Roth BL, Armbruster B, Watts VJ, Nichols DE. WAY-100635 is a potent dopamine D4 receptor agonist. Psychopharmacology. 2006;188:244-51.

19. Moreland RB, Patel M, Hsieh GC, Wetter JM, Marsh K, Brioni JD. A-412997 is a selective dopamine D4 receptor agonist in rats. Pharmacol Biochem Behav. 2005;82:140-7.

20. Browman KE, Curzon P, Bao Pan J, Molesky AL, Komater VA, Decker MW, Brioni JD, Moreland RB, Fox GB. A-412997, a selective dopamine D4 agonist, improves cognitive performance in rats. Pharmacol Biochem Behav. 2005;82:148-55.

21. Patel MV, Kolasa T, Mortell K, Matulenko MA, Hakeem AA, Rohde JJ, Nelson SL, Cowart MD, Nakane M, Miller LN, Uchic ME, Terranova MA, El-Kouhen OF, Donnelly-Roberts DL, Namovic MT, Hollingsworth PR, Chang R, Martino BR, Wetter JM, Marsh KC, Martin R, Darbyshire JF, Gintant G, Hsieh GC, Moreland RB, Sullivan JP, Brioni JD, Stewart AO. Discovery of 3-methyl- $N$-(1-oxy-3ф,4ф,5ф,6ф-tetrahydro- $2 \phi \mathrm{H}$-[2,4ф-bipyridine]$1 \phi$-ylmethyl)benzamide(ABT-670), an orally bioavailable dopamine D4 agonist for the treatment of erectile dysfunction. J Med Chem. 2006;49:7450-65.

22. Ford JL, Timmins P. Pharmaceutical thermal analysis: techniques and applications. New York: Wiley; 1989.

23. Haines PJ. Thermal methods of analysis-principles, applications and problems. London: Blackie Academic and Professional; 1995.

24. Charsley EL, Warrington SB. Thermal analysis: techniques and applications. Cambridge: Royal Society of Chemistry; 1992.

25. Craig Duncan QM, Reading M. Thermal analysis of pharmaceuticals. Boca Raton: CRC Press; 2007.

26. Giron D. Applications of thermal analysis and coupled techniques in pharmaceutical industry. J Therm Anal Cal. 2002;68(2):335-57.

27. Zayed MA, Hawash MF, Fahmey MA, Ali El-Gizouli MM. Investigation of ibuprofen drug using mass spectrometry, thermal analyses, and semi-empirical molecular orbital calculation. J Therm Anal Cal. 2012;108(1):315-22.

28. Kohutová A, Honcová P, Svoboda L, Bezdička P, Maříková M. Structural characterization and thermal behaviour of biological hydroxyapatite. J Therm Anal Cal. 2012;108(1):167-73.

29. Pani NR, Nath LK, Acharya S, Bhuniya B. Application of DSC, IST, and FTIR study in the compatibility testing of nateglinide with different pharmaceutical excipients. J Therm Anal Cal. 2012; 108(1):219-26.

30. El-Gamel Nadia EA, Hawash MF, Fahmey MA. Structure characterization and spectroscopic investigation of ciprofloxacin drug. J Therm Anal Cal. 2012;108(1):253-62.

31. Thakur SS, Maheswaram MPK, Mantheni DR, Kaza L, Perara I, Ball DW, Moran J, Riga AT. Solid-state mechanical properties of crystalline drugs and excipients. J Therm Anal Cal. 2012;108(1):283-7.

32. Frisch MJ, Trucks GW, Schlegel HB, Scuseria GE, Robb MA, Cheeseman JR, Montgomery JA, Vreven T, Kudin KN, Burant JC, Millam JM, Iyengar SS, Tomasi J, Barone V, Mennucci B, Cossi M, Scalmani G, Rega N, Petersson GA, Nakatsuji H, Hada M, Ehara M, Toyota K, Fukuda R, Hasegawa J, Ishida M, Nakajima T, Honda Y, Kitao O, Nakai H, Klene M, Knox JE, Hratchian HP, Cross JB, Adamo C, Jaramillo J, Gomperts R, Stratmann RE, Yazyev O, Austin AJ, Cammi R, Pomelli C, Ochterski JW, Ayala PY, Morokuma K, Voth GA, Salvador P, Dannenberg JJ, Zakrzewski VG, Dapprich S, Daniels AD, Strain MC, Farkas O, Malick DK, Rabuck AD, Raghavachari K, Foresman JB, Ortiz JV, Cui Q, Baboul AG, Clifford S, Cioslowski J, Stefanov BB, Liu G, Liashenko A, Piskorz P, Komaromi I, Martin RL, Fox DJ, Keith T, Al-Laham MA, Peng CY, Nanayakkara A, Challacombe M, Gill PMW, Johnson B, Chen W, Wong MW, Gonzalez C, Pople JA. Gaussian 03. Pittsburgh: Gaussian Inc.; 2003.

33. Becke AD. Density-functional thermochemistry. III. The role of exact exchange. J Chem Phys. 1993;98:5648-53. 
34. Lee C, Yang W, Parr RG. Development of the Colle-Salvetti correlation energy formula into a functional of the electron density. Phys Rev. 1988;B37:785-9.

35. Perdew JP, Wang Y. Accurate and simple analytic representation of the electron-gas correlation energy. Phys Rev. 1992;B45:13244-9.

36. Karczmarzyk Z. Keto-enol tautomerism in crystals of 3-[hydroxy(phenyl)methyl]-2,5,7 trimethyl-2,3-dihydropyrido[3,2-e]-[1, 2]thiazin-4-one 1,1-dioxide and 3-(1-hydroxyethylidene)-2,5, 7-trimethyl-2,3-dihydropyrido[3,2-e][1, 2]-thiazin-4-one 1,1-dioxide. Acta Crystallogr. 2008;C64:590-4.
37. Roohi H, Nowroozi AR, Anjomshoa E. H-bonded complexes of uracil with parent nitrosamine: a quantum chemical study. Comput Theor Chem. 2011;965:211-20.

38. Munshi P, Guru Row TN. Intra- and intermolecular interactions in small bioactive molecules: cooperative features from experimental and theoretical charge-density analysis. Acta Crystallogr. 2006;B62:612-26. 